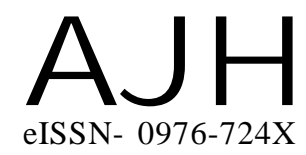

Received : 29.02.2016

Revised : 21.04 .2016

Accepted : 01.05.2016

\title{
Influence of gamma radiations and EMS on morphological characteristics of gladiolus cv. PINK BEAUTY
}

Members of the Research Forum Associated Authors:

${ }^{1}$ Department of Horticulture, C.C.S. Haryana Agricultural University, HISAR (HARYANA) INDIA

${ }^{2}$ Department of Genetics and Plant Breeding, C.C.S. Haryana Agricultural University, HISAR (HARYANA) INDIA

Author for correspondence : MONIKA YADAV

Department of Horticulture, C.C.S. Haryana Agricultural University, HISAR (HARYANA) INDIA

\section{MONIKA YADAV, VINITA RAJPUT ${ }^{1}$, R.S. SAHARAN ${ }^{2}$, S.K. SEHRAWAT ${ }^{1}$ AND RAVIKA ${ }^{2}$}

ABSTRACT : The corms of gladiolus cv. PINK BEAUTY were treated with gamma rays $(0,3,6$, $9 \mathrm{kR})$, EMS (0. 0.2, 0.4, $0.6 \%$ ) both alone and in combination including control i.e. untreated. Different vegetative, floral and corm parameters were recorded. The days taken for sprouting of corms were delayed after treatment with gamma rays and recorded maximum at $6 \mathrm{kR}+0.2 \%$ (26.78 days). Duration of sprouting was decreased by EMS and was observed to be maximum at $3 \mathrm{kR}$ gamma rays $(100 \%)$. The gladiolus plants could not survive in treatments of gamma rays and its combination with EMS. On the basis of above observations, it may be concluded that 0.2 to 0.6 per cent EMS doses are suitable for inducing mutation in gladiolus.

KEY WORDS : Gladiolus, Gamma rays, EMS, Sprouting

HOW TO CITE THIS ARTICLE : Yadav, Monika, Rajput, Vinita, Saharan, R.S., Sehrawat, S.K. and Ravika (2016). Influence of gamma radiations and EMS on morphological characteristics of gladiolus cv. PINK BEAUTY. Asian J. Hort., 11(1) : 114-118, DOI : 10.15740/HAS/TAJH/11.1/114-118. 